\title{
Steam gasification of safflower seed cake and catalytic tar decomposition over ceria modified iron oxide catalysts
}

\author{
Gozde Duman a , Taichi Watanabe ${ }^{\mathrm{b}}$, Md. Azhar Uddin ${ }^{\mathrm{b}}$, Jale Yanik ${ }^{\mathrm{c}, *}$ \\ a Faculty of Science, Department of Chemistry, Izmir Institute of Technology, 35430 Urla, Izmir, Turkey \\ ${ }^{\mathrm{b}}$ Department of Environmental Chemistry and Materials, Okayama University, 3-1-1 Tsushima, Naka, Okayama 700-8530, Japan \\ c Faculty of Science, Department of Chemistry, Ege University, 35100 Bornova, Izmir, Turkey
}

\section{A R T I C L E I N F O}

\section{Article history:}

Received 11 February 2014

Received in revised form 29 April 2014

Accepted 30 April 2014

Available online 27 May 2014

\section{Keywords:}

Biomass

Steam gasification

Iron catalyst

Ceria catalyst

Tar decomposition

\begin{abstract}
A B S T R A C T
Catalytic steam gasification of safflower seed cake was carried out using a double-bed microreactor in a two-stage process in the presence of ceria oxide $\left(\mathrm{CeO}_{2}\right)$ modified iron oxide $\left(\mathrm{Fe}_{2} \mathrm{O}_{3}\right)$ catalysts with different $\mathrm{CeO}_{2}-\mathrm{Fe}_{2} \mathrm{O}_{3}$ ratios. The effects of both catalyst and the temperature of catalytic bed on the tar decomposition and the overall gaseous product yield were investigated comparatively. It was found that ceria modified iron oxide catalysts had higher reactivity than that of the individual $\mathrm{Fe}_{2} \mathrm{O}_{3}$ and $\mathrm{CeO}_{2}$ for the catalytic tar decomposition in safflower seed cake steam gasification. The $\mathrm{CeO}_{2}-\mathrm{Fe}_{2} \mathrm{O}_{3}$ catalyst with 50 wt.\% of $\mathrm{Fe}_{2} \mathrm{O}_{3}$ exhibited the excellent performance for tar conversion at $700{ }^{\circ} \mathrm{C}$. A comparison of tar decomposition from thermal run and catalytic run showed that in thermal run tar decomposition was progressed via steam reforming only. However, in the presence of catalyst, tar decomposition occurred via both steam reforming and water gas shift reaction. As a conclusion, ceria promoted iron catalysts were found to be active for both hydrogen production and tar decomposition in steam gasification of lignocellulosic biomass.
\end{abstract}

(C) 2014 Elsevier B.V. All rights reserved.

\section{Introduction}

Conversion of lignocellulosic biomass to synthesis gas is one of the important technologies for the energy utilization of biomass as renewable organic resources. Biomass gasification is one of the most promising thermochemical processes to produce syngas and fuel gas. There are many studies of biomass gasification using different agents such as carbon dioxide $\left(\mathrm{CO}_{2}\right)$, steam, and air. Steam gasification has more advantages among the other agents. Some studies showed that the steam gasification reaction is much faster than the $\mathrm{CO}_{2}$ gasification [1]. Furthermore, for steam gasification, the produced gas contains hydrogen $\left(\mathrm{H}_{2}\right)$ and carbon monoxide $(\mathrm{CO})$ which can be used as fuel gas or raw material for chemical synthesis depending on the gas composition [2]. The use of steam increases hydrogen production due to the water-gas-shift, steam reforming and water-gas reactions.

The main problem of gasification in general is the formation of tar, since it creates severe problems in syngas utilization. Tar formed during gasification is removed by physical methods, using various types of filter or scrubber and cyclones [3]. On the other hand, catalytic decomposition can be considered as the best promising technique for tar elimination because they can be also converted into useful products besides completely destroyed. In literature, considerable research concerning the catalytic decomposition of tar has been undertaken and several

\footnotetext{
* Corresponding author. Tel./fax: +90232 3888264.

E-mail address: jale.yanik@ege.edu.tr (J. Yanik).
}

types of catalysts have been tested to decompose tar either in bed as primary catalysts $[4,5]$ or in downstream reactor as secondary catalyst [6-8].

Nickel-based steam reforming catalysts, well known and commercially available, have been proven to be very active in tar reduction. But the catalyst deactivation due to the sintering and/or coke deposition is one of the serious problems for nickel ( $\mathrm{Ni}$ ) catalysts. Besides $\mathrm{Ni}$ catalysts, dolomites and olivine have been extensively investigated as biomass gasification catalysts $[9,10]$ because they are inexpensive and abundant and can reduce the tar content of the product gas. They can be used as a primary catalyst (in bed) as well as secondary, downstream. But they have some drawbacks. For example, they are significantly active above $800{ }^{\circ} \mathrm{C}$ which is not a desirable temperature if catalyst is used as secondary catalyst. In addition, their activity depends on iron(III) oxide $\left(\mathrm{Fe}_{2} \mathrm{O}_{3}\right)$ contents. It was found that a different dolomite has different activities due to the different $\mathrm{Fe}_{2} \mathrm{O}_{3}$ contents and pore diameters $[11,12]$.

The iron based catalysts are another important group of active catalysts and have been applied extensively for biomass gasification and tar conversion $[13,14]$ because of their high tar destruction activity, as well as the reforming of light hydrocarbon activity. Uddin et al. have developed [13] iron-based catalysts for the decomposition of tar derived from cedar wood gasification in a two stage reactor by steam reforming. The tar was decomposed to hydrogen rich gasses over the iron oxide catalysts by water gas shift reaction. It was suggested that the reduced iron species are the active sites on iron oxide catalysts in steam 
reforming [15]. Matsuoka et al. also reported that the addition of iron promoted hydrogen formation in the decomposition of tar derived from steam gasification of wood chips over iron/alumina catalysts [14, $16]$.

Although, for the Ni, catalyst deactivation due to coke deposition could be a serious problem, it was found that the addition of ceria (Ce) into the nickel ( $\mathrm{Ni}$ ) catalysts promoted the gasification of the deposited carbon, which led to increase in the stability of the catalyst, as well as the water-gas shift reaction, and as a result, the stability of the catalyst was improved [17]. Ceria oxide $\left(\mathrm{CeO}_{2}\right)$ can be considered as a promoter, which increases activity and/or selectivity, and a support that provides the dispersion of the active phase [18]. It was reported that lattice oxygen from the ceria support could oxidize carbon produced from methane decomposition resulting in the formation of $\mathrm{CO}$ and maintaining the catalytic activity of $\mathrm{Ni}-\mathrm{CeO}_{2}[19]$. Zhang et al. investigated the effect of ceria addition to a $\mathrm{Ni} /$ olivine catalyst for steam reforming of benzene or toluene and they found that $\mathrm{CeO}_{2}$ addition to $\mathrm{Ni} /$ olivine enhanced tar conversion, $\mathrm{H}_{2}$ production, and coke resistance [20]. In the case of steam reforming of bio-oil, it was found that ceriazirconia supported catalysts are more active than those aluminasupported, both in terms of carbon oxides $\left(\mathrm{CO}_{\mathrm{x}}\right)$ yield and hydrogen production [12]. Asadullah et al. performed catalytic gasification of cellulose [21] with the $\mathrm{Rh} / \mathrm{CeO}_{2} / \mathrm{M}\left(\mathrm{M}: \mathrm{SiO}_{2}, \mathrm{Al}_{2} \mathrm{O}_{3}\right.$, and $\left.\mathrm{ZrO}_{2}\right)$ type catalysts with various compositions, the conventional nickel and dolomite catalysts in a fluidized bed gasifier at $500-700{ }^{\circ} \mathrm{C}$. They reported that $\mathrm{CeO}_{2}$ is very effective to the enhancement of carbon conversion and $\mathrm{Rh}$ catalyst provided much better results than conventional Ni and dolomite catalysts. Ceria has well-known redox properties, shows promising catalytic activities and selectivity in partial oxidation because of its oxygen storage ability on the basis of $2 \mathrm{CeO}_{2} \rightarrow \mathrm{Ce}_{2} \mathrm{O}_{3}+1 / 2 \mathrm{O}_{2}$. It was suggested that reduced $\mathrm{Ce}$ species can be oxidized with steam, and $\mathrm{CeO}_{2}$ can be regenerated [22]. It has also the ability to promote metalceria interaction and metal dispersion [23]. The redox features of ceria could be greatly enhanced by the addition of transition metals as well as noble metals, and the improvement in catalytic performance was often attributed to the strong metal-ceria interaction and the generation of metal-ceria solid solutions. $\mathrm{CeO}_{2}$ has also been reported to prohibit coke deposition on catalysts $[6,24,25]$. In literature, ceria supported catalyst has been used mainly in the gasification of bio-oil derived from biomass pyrolysis and bio-oil model compounds. Therefore, the use of $\mathrm{CeO}_{2}$ as support and catalyst promoter is an interesting application for steam gasification of biomass.

On the basis of the above literature reports, combined application of $\mathrm{CeO}_{2}$ and $\mathrm{Fe}_{2} \mathrm{O}_{3}$ catalysts looks promising. The present work follows from the previous investigation on catalytic decomposition of biomass tars with iron oxide catalysts carried out by Uddin et al. [13]. In the present study, ceria modified iron catalysts with varying amounts of iron (from 10 to $90 \%$ ) were prepared and used in steam gasification of safflower seed cake. One of the aims of this study is the tar conversion during gasification of safflower seed cake, as well as hydrogen production.

\section{Material and methods}

\subsection{Materials}

Safflower seed cake (a by-product of safflower oil production) was provided by an oil company (Sivas, Turkey). It was ground to particle size less than $2 \mathrm{~mm}$ and then dried overnight at $105^{\circ} \mathrm{C}$. The proximate, ultimate and component analyses of seed cake are shown in Table 1. Thermogravimetric analysis of biomass showed that volatilization occurred between 250 and $500{ }^{\circ} \mathrm{C}$ and then the weight loss reached a plateau after about $500{ }^{\circ} \mathrm{C}$.

$\mathrm{CeO}_{2}-\mathrm{Fe}_{2} \mathrm{O}_{3}$ with different ratios was prepared by coprecipitation method using ammonia as precipitating agent. Starting materials were iron nitrate hexahydrate $\left(\mathrm{Fe}\left(\mathrm{NO}_{3}\right)_{3} \cdot 9 \mathrm{H}_{2} \mathrm{O}\right)$ and cerium nitrate
Table 1

Some properties of safflower seed cake.

\begin{tabular}{lr}
\hline Proximate analysis [as received, wt.\%] & \\
\hline Moisture & 11.2 \\
Volatile matter & 70.3 \\
Fixed carbon & 15.6 \\
Ash & 2.9 \\
Ultimate analysis [dry, wt.\%] & \\
\hline C & 49.8 \\
H & 5.8 \\
N & 3.4 \\
S & 0.2 \\
Oa & 40.8 \\
Component analysis, [dry, wt.\%] & \\
\hline Cellulose & 22.5 \\
Hemicellulose & 39.5 \\
Lignin & 33.5 \\
Extractives & 4.5 \\
\hline
\end{tabular}

${ }^{\text {a }}$ Calculated from difference.

hexahydrate $\left(\mathrm{Ce}\left(\mathrm{NO}_{3}\right)_{3} \cdot 9 \mathrm{H}_{2} \mathrm{O}\right) .20 \mathrm{wt}$.\% of the iron salt or the mixture of the salts is added to a required amount ( $10 \%$ in excess of the stoichiometric amount) of $7 \mathrm{wt} . \%$ ammonia water solution quickly and stirred vigorously. The precipitate was washed with deionized water. The precipitate was then filtered and dried at $110{ }^{\circ} \mathrm{C}$ for $24 \mathrm{~h}$ and calcined at $700{ }^{\circ} \mathrm{C}$ in air for $1 \mathrm{~h}$. The calcined samples were crushed and sieved into an average size of $0.367 \mathrm{~mm}$. The various $\mathrm{CeO}_{2}-\mathrm{Fe}_{2} \mathrm{O}_{3}$ catalysts were referred to as $\mathrm{x} \% \mathrm{CeO}_{2}-\mathrm{y} \% \mathrm{Fe}_{2} \mathrm{O}_{3}$, in which $\mathrm{x}$ and $\mathrm{y}$ are the weight percentage of $\mathrm{CeO}_{2}$ and $\mathrm{Fe}_{2} \mathrm{O}_{3}$, respectively.

The surface area and bulk density of the investigated catalysts are shown in Table 2. The powder X-ray diffraction (XRD) pattern of the catalysts was recorded using a Shimadzu XRD-6100 diffractometer with $\mathrm{CuK} \alpha$ irradiation $(30 \mathrm{kV}, 30 \mathrm{~mA})$.

\subsection{Gasification setup}

Gasification of biomass is carried out in a two stage (fixed-bed) quartz reactor. The schematic diagram of experimental set-up has been given in the previous study [13]. The experimental procedure involved the following steps: in a typical run, a very small amount of biomass sample $(0.04 \mathrm{~g}$, particle size: $0.15-0.30 \mathrm{~mm})$ was placed in the top section on a quartz wool bed and the desired amount $(0.065 \mathrm{ml})$ of catalyst was placed on the second quartz wool bed. The reactor system was purged with nitrogen $\left(\mathrm{N}_{2}\right)$ flow for $30 \mathrm{~min}$, while a mixture of water vapor $\left(\mathrm{H}_{2} \mathrm{O}\right)$ generated in a bubbler at $70{ }^{\circ} \mathrm{C}$ and $\mathrm{N}_{2}$ with a composition of $30 \% \mathrm{H}_{2} \mathrm{O}-\mathrm{N}_{2}$ at flow rate of $20 \mathrm{~cm}^{3}$ STP (Standard Temperature and Pressure)/min was passed through the reactor bypass. Both nitrogen and steam flows were chosen based on the previous study [13] in this reactor system. In the meantime, the bottom bed (catalyst bed) was heated to the predetermined temperature $\left(600-850{ }^{\circ} \mathrm{C}\right)$ at rate of $3{ }^{\circ} \mathrm{C} / \mathrm{min}$ in $\mathrm{N}_{2}$ flow. When the bottom bed (catalyst bed) temperature reached the desired temperature, heating of the top bed (biomass bed) to the $850{ }^{\circ} \mathrm{C}$ commenced at a heating rate of $3{ }^{\circ} \mathrm{C} / \mathrm{min}$ and a

Table 2

Surface area of catalysts.

\begin{tabular}{lc}
\hline Catalyst & Surface area $\left(\mathrm{m}^{2} / \mathrm{g}\right)$ \\
\hline $100 \% \mathrm{Fe}_{2} \mathrm{O}_{3}$ & 1.7 \\
$10 \% \mathrm{CeO}_{2}-90 \% \mathrm{Fe}_{2} \mathrm{O}_{3}$ & 11.2 \\
$30 \% \mathrm{CeO}_{2}-70 \% \mathrm{Fe}_{2} \mathrm{O}_{3}$ & 11.4 \\
$50 \% \mathrm{CeO}_{2}-50 \% \mathrm{Fe}_{2} \mathrm{O}_{3}$ & 11.2 \\
$70 \% \mathrm{CeO}_{2}-30 \% \mathrm{Fe}_{2} \mathrm{O}_{3}$ & 16.5 \\
$90 \% \mathrm{CeO}_{2}-10 \% \mathrm{Fe}_{2} \mathrm{O}_{3}$ & 31.7 \\
$100 \% \mathrm{CeO}_{2}$ & 33.8 \\
\hline
\end{tabular}


mixture of $30 \% \mathrm{H}_{2} \mathrm{O}-\mathrm{N}_{2}$ was passed through the reactor. When the top bed (biomass bed) temperature reached $200{ }^{\circ} \mathrm{C}$, analysis of the reactor outlet gas (product gas) was started with an online gas chromatograph during heating. Product gas was also collected in two sampling bags at different time intervals. The online GC analyses were performed during heating at different time intervals. The product gasses are analyzed with two online gas chromatographs equipped with a TCD and three columns: a molecular sieve 13 column was used to analyze $\mathrm{H}_{2}$ with $\mathrm{Ar}$ carrier and $\mathrm{O}_{2}, \mathrm{CO}$ and $\mathrm{CH}_{4}$ were analyzed with He carrier; a Porapak QS column with He carrier was used to analyze $\mathrm{CO}_{2}$, methane $\left(\mathrm{CH}_{4}\right)$ and ethylene $\left(\mathrm{C}_{2} \mathrm{H}_{4}\right)$. This micro-reactor system is very convenient for the evaluation the catalytic activity and gas yields. Due to the low amount of the bio-mass sample used in this study (about $0.04 \mathrm{~g}$ in each run of experiment), tar product could not be analyzed. Therefore, we evaluated the activity of the catalysts and the gas yields by using the data of the gaseous products only.

\section{Results and discussion}

\subsection{Non-catalytic gasification of safflower seed cake}

In our experimental system, the decomposition of biomass with steam proceeds in the following steps: pyrolysis of biomass and evolution of volatile matters including tars at $200-500{ }^{\circ} \mathrm{C}$; and steam gasification of char between 500 and $850{ }^{\circ} \mathrm{C}$ in the top bed (biomass bed). It has reported that a temperature over $850{ }^{\circ} \mathrm{C}$ is high enough for steam gasification of char [26]. The temperature of top bed was thus chosen as $850{ }^{\circ} \mathrm{C}$ in the present study.

Fig. 1(a) shows the distribution of main gaseous products obtained from steam gasification of safflower oil cake with no catalyst in the bottom bed (bed temperature: $850{ }^{\circ} \mathrm{C}$ ) as a function of the biomass bed temperature. As seen from Fig. 1(a), the gasses were formed in two temperature ranges with peaks around $300{ }^{\circ} \mathrm{C}$ and $800{ }^{\circ} \mathrm{C}$. In the first temperature region, mainly $\mathrm{CO}, \mathrm{CO}_{2}$ and some $\mathrm{H}_{2}, \mathrm{CH}_{4}$ and $\mathrm{C}_{2} \mathrm{H}_{4}$ evolved. In the second temperature region, predominantly $\mathrm{H}_{2}$ and $\mathrm{CO}_{2}$ evolved. The product distribution for volatile matters gasification and char gasification is shown in Fig. 1(b).

In this study, the product gasses were analyzed via online gas chromatography at every $15 \mathrm{~min}$ and also the gasses collected in two separate Tedlar bags were analyzed off-line. It is noteworthy that $\mathrm{CO}_{2}$ was not analyzed on-line, but off-line. In off-line analysis by gas chromatography, product gas was collected in two Tedlar sampling bags, tar evaluation $\left(200-500{ }^{\circ} \mathrm{C}\right)$ phase in one set of bags and char gasification $\left(500-850{ }^{\circ} \mathrm{C}\right)$ phase in another set of bags. Gas yield was defined as the cumulative amount of gas produced per unit weight of biomass on a dry basis. Fig. 2(a) shows the effect of bottom bed temperature on the total yield of carbon (based on total carbon amount of biomass) for volatile matters and char gasification products. The carbon yields
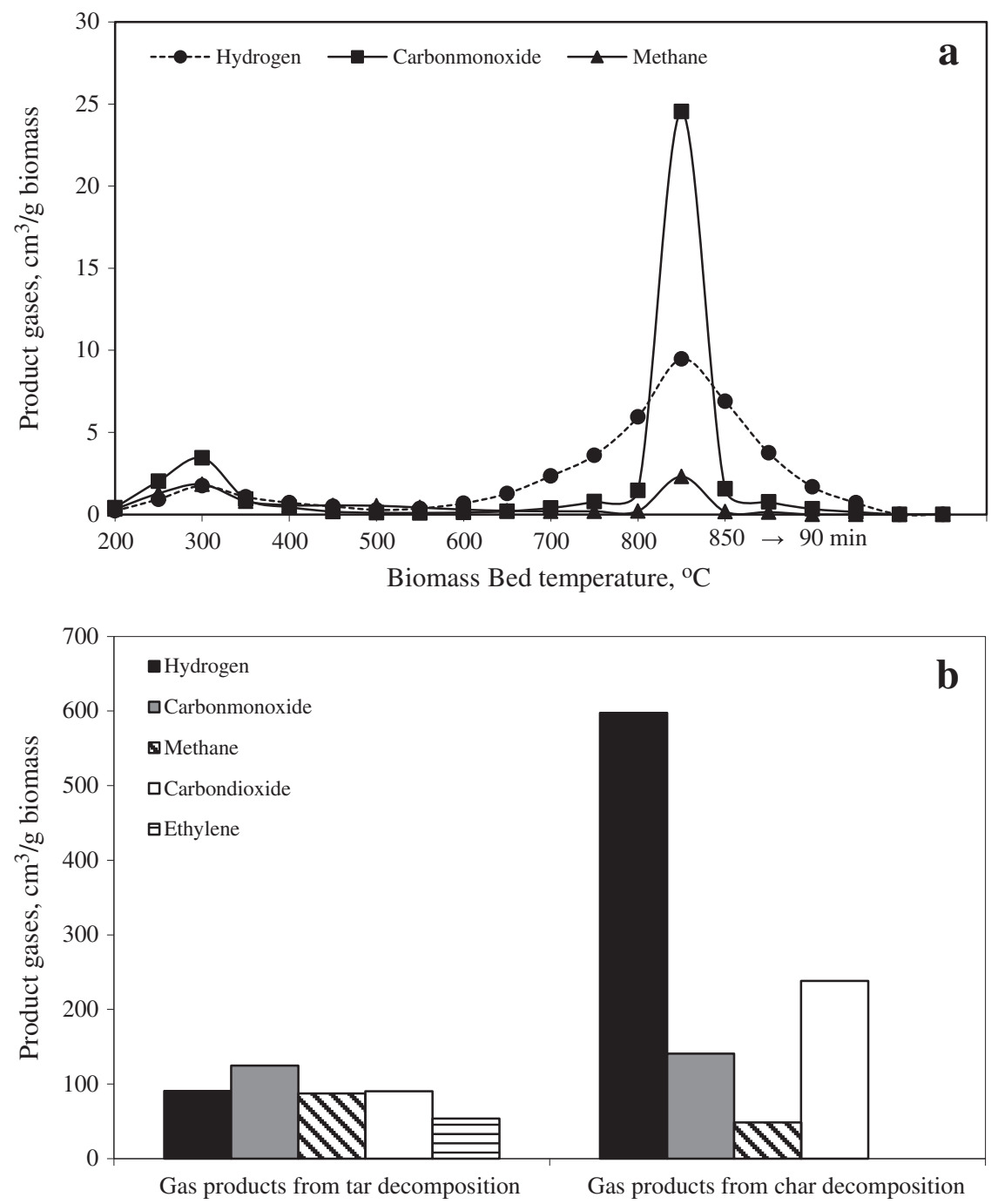

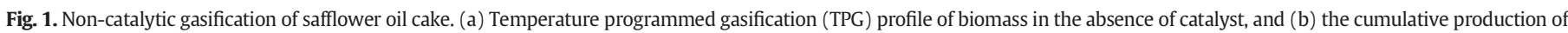
gaseous products from volatile matters and char (bottom bed temperature: $850{ }^{\circ} \mathrm{C}$ ). 

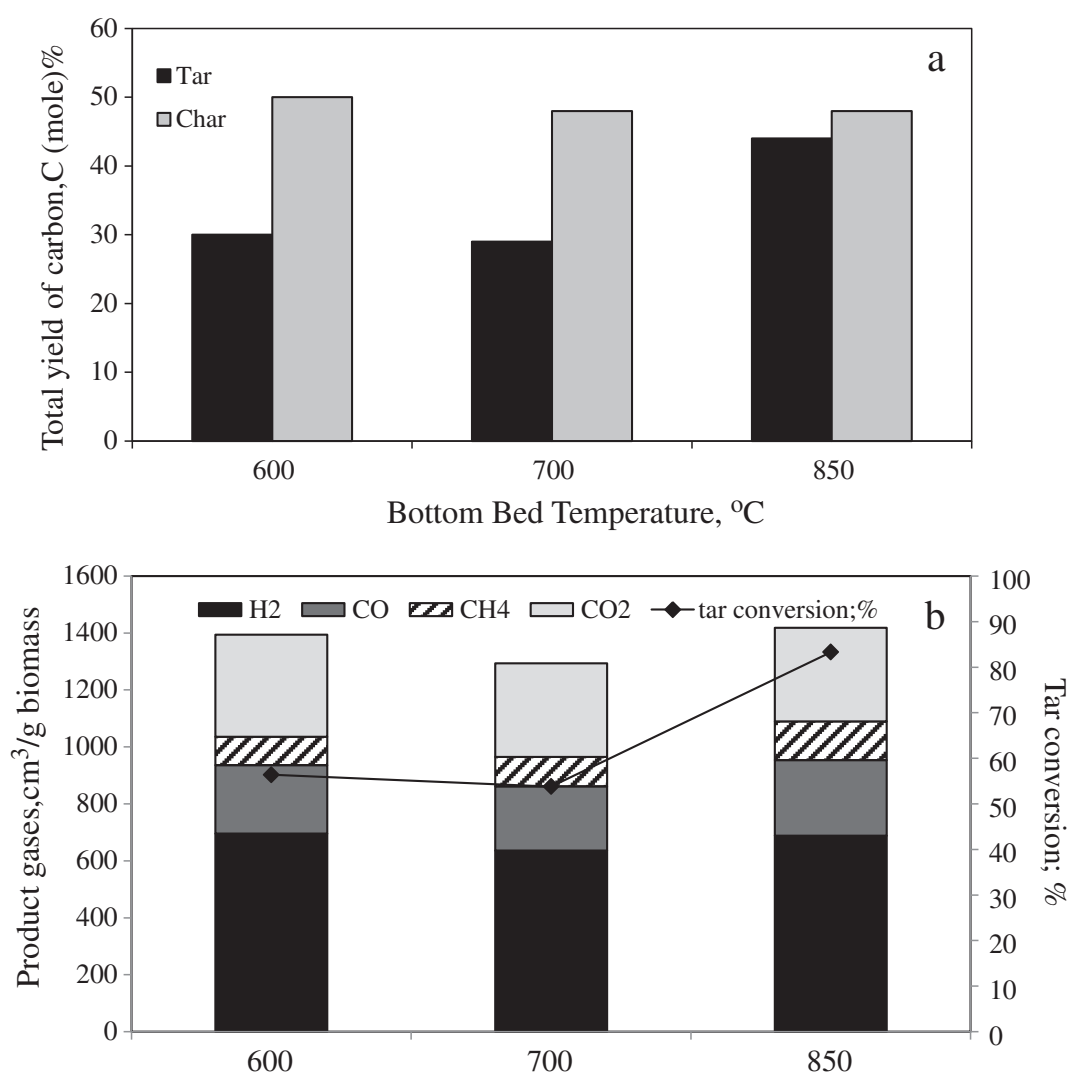

Bottom Bed Temperature, ${ }^{\circ} \mathrm{C}$

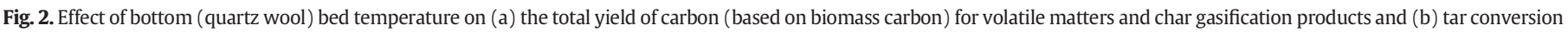
and gas production for noncatalytic thermal steam gasification.

were calculated from off-line gas analysis data for $\mathrm{CO}, \mathrm{CO}_{2}, \mathrm{CH}_{4}$ and $\mathrm{C}_{2} \mathrm{H}_{4}$. Thus, the carbon yield of volatile matter was calculated by dividing carbon content of gasses emitted between 200 and $500{ }^{\circ} \mathrm{C}$ (biomass bed temperature). The percent of carbon yield of char gasification was calculated by dividing the carbon content of gasses emitted during char gasification $\left(500-850^{\circ} \mathrm{C}\right)$ by the carbon content in biomass.

As seen from Fig. 2(a), the carbon yield from char gasification was almost the same in three different bottom bed temperatures. This result is reasonable because temperatures of the top bed were the same in these experiments. In the steam gasification of cedar sawdust in same microreactor, Uddin et al. obtained similar results [13]. In their study, the yield of carbon in gaseous product from char was almost the same (ca. 36\%) for different bottom bed temperatures $\left(600-850{ }^{\circ} \mathrm{C}\right)$ when the biomass bed temperature (top bed) was $850{ }^{\circ} \mathrm{C}$. In our study, the yield of carbon from the char was around $48 \%$ for each experimental run. Therefore, if all of the volatile matter (including tars) content of the biomass is decomposed into gaseous products, the carbon content of the volatile matters (including tars) should be about $52 \%$, by assuming that the total carbon yield of steam gasification is $100 \%$. When the temperature of bottom bed was increased from 700 to $850{ }^{\circ} \mathrm{C}$ in the absence of catalyst, the total gas yield increased (Fig. 2(b)), indicating that higher temperature promotes thermal cracking of tar. A significant increase in noncatalytic tar conversion by the temperature of bottom bed supports this conclusion. Tar conversion increased from $53.8 \%$ to $83.3 \%$ by the increasing of bottom bed temperature from $700{ }^{\circ} \mathrm{C}$ to $850{ }^{\circ} \mathrm{C}$ (Fig. 2b). It seems that the formation of $\mathrm{H}_{2}, \mathrm{CO}$ and $\mathrm{CH}_{4}$ was promoted by increasing the temperature of bottom bed while the amount of $\mathrm{CO}_{2}$ was constant. We can conclude that thermal steam gasification only brought about tar decomposition via steam reforming however, water gas shift reaction did not occur when increasing the temperature from 700 to $850{ }^{\circ} \mathrm{C}$.

\subsection{Catalytic gasification of safflower seed cake}

\subsubsection{Effect of catalyst on gas composition from steam gasification}

In the present experimental system, the following reaction pathways are possible: (1) devolatilization of biomass (between 200 and $\left.500{ }^{\circ} \mathrm{C}\right)$, (2) steam reforming of char (between 500 and $\left.850{ }^{\circ} \mathrm{C}\right),(3)$ reforming of tar on the catalyst, (4) the water-gas shift reaction (WGSR) on the catalyst, and (5) the steam-iron reaction. The catalyst can show different activities for 3 and 4 reaction pathways, whereas reaction pathways 1 and 2 are independent of the catalyst. It would be expected that the reaction pathway 5 is effective at higher temperature [27].

The effect of catalyst on the gasification of biomass was investigated by the temperature programmed steam gasification of biomass in the top bed at $200-850{ }^{\circ} \mathrm{C}$ followed by the catalytic gasification of tar in the bottom bed at the constant temperatures of 600 and $700{ }^{\circ} \mathrm{C}$ at a SV of $1.85 \times 10^{4} \mathrm{~h}^{-1}$.

Fig. 3 shows the yield of each gas from catalytic gasification using $\mathrm{CeO}_{2}-\mathrm{Fe}_{2} \mathrm{O}_{3}$ catalysts with different Ce contents. Results were compared to those obtained with unicomponent catalysts such as $\mathrm{CeO}_{2}$ and $\mathrm{Fe}_{2} \mathrm{O}_{3}$. From Figs. 3 and 2(b) together, a significant change in the cumulative production of gasses is clearly seen due to the presence of catalyst. $\mathrm{H}_{2}$ and $\mathrm{CO}_{2}$ production increased, whereas $\mathrm{CO}$ production decreased with the use of $\mathrm{CeO}_{2}-\mathrm{Fe}_{2} \mathrm{O}_{3}$ catalysts. The amount of increment of $\mathrm{H}_{2}$ varied with the content of $\mathrm{CeO}_{2}$. But it should be noted that both $\mathrm{CeO}_{2}$ and $\mathrm{Fe}_{2} \mathrm{O}_{3}$ alone also showed the activity for the tar gasification. For the catalytic bed temperature of $700{ }^{\circ} \mathrm{C}$, by using of $\mathrm{CeO}_{2}$ alone, $\mathrm{H}_{2}$ yield increased from $690 \mathrm{~cm}^{3} / \mathrm{g}$ biomass (in the thermal case) to $1176 \mathrm{~cm}^{3} / \mathrm{g}$ biomass whereas $\mathrm{CO}$ yield decreased from $240 \mathrm{~cm}^{3} / \mathrm{g}$ biomass to $88 \mathrm{~cm}^{3} / \mathrm{g}$ biomass. In the case of $\mathrm{Fe}_{2} \mathrm{O}_{3}$ alone, the yields of $\mathrm{H}_{2}$ and $\mathrm{CO}$ 

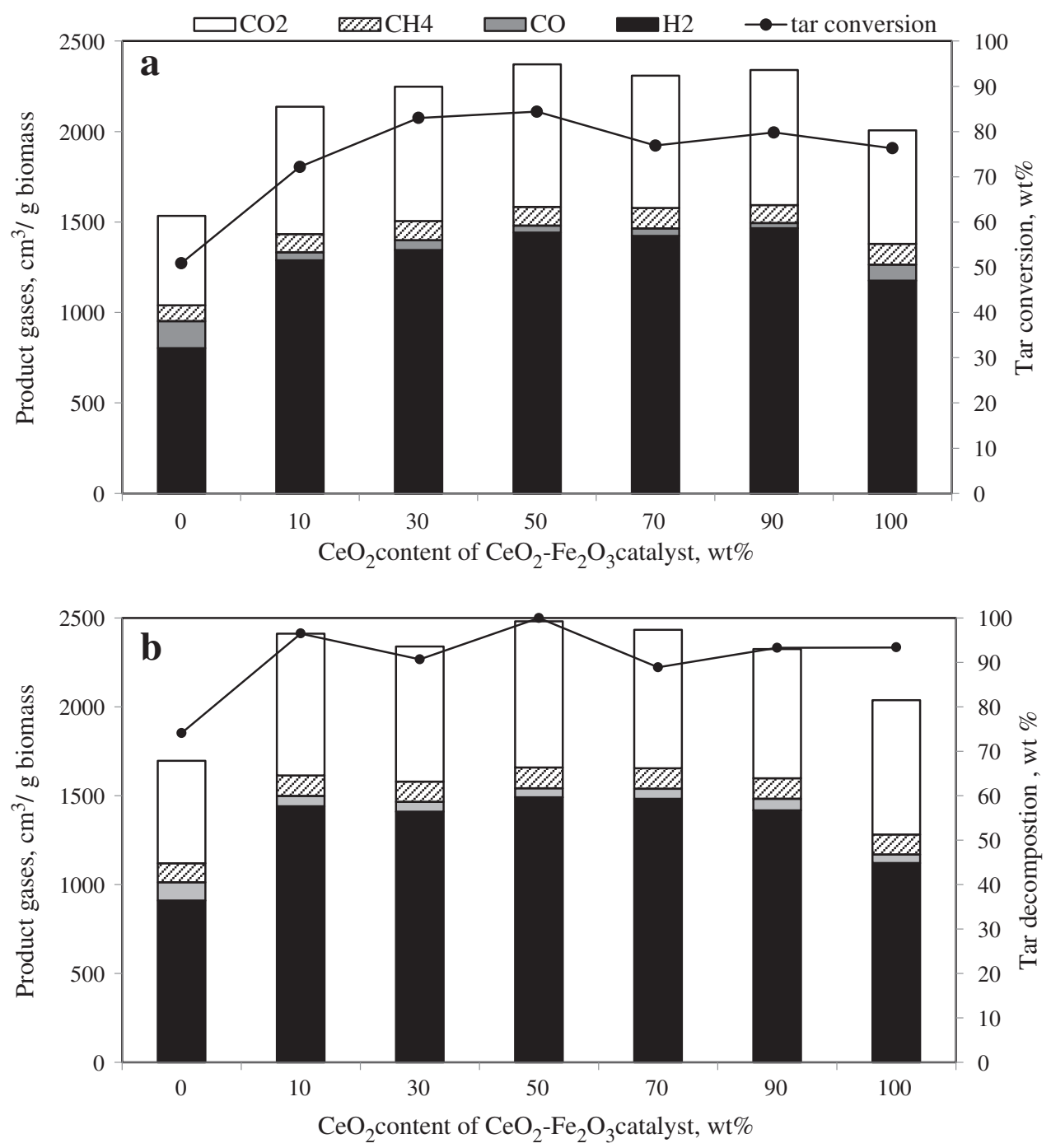

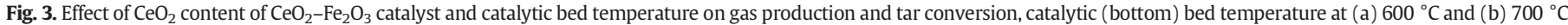
(biomass bed temperature is increased to $850{ }^{\circ} \mathrm{C}$ with heating rate $3^{\circ} \mathrm{C} \mathrm{min}-1$ ).

were 803 and $149 \mathrm{~cm}^{3} / \mathrm{g}$ biomass, respectively. As it is known, the reduction in the $\mathrm{CO}$ content is desirable when the maximum hydrogen production is aimed.

Moreover there is no significant influence of catalyst on $\mathrm{CH}_{4}$ production. Uddin et al. investigated the steam gasification of cedar sawdust on $\mathrm{Fe}_{2} \mathrm{O}_{3}$ catalysts [13]. They reported that, in comparison to the noncatalytic gasification, the production of $\mathrm{H}_{2}$ and $\mathrm{CO}_{2}$ increased while the production of $\mathrm{CO}$ decreased in the presence of catalyst. And they suggested that biomass tar is decomposed first over the catalyst to gasses such as $\mathrm{CO}, \mathrm{H}_{2}, \mathrm{CO}_{2}, \mathrm{CH}_{4}, \mathrm{C}_{2} \mathrm{H}_{4}$ and other hydrocarbons. And then the $\mathrm{CO}$ derived from tar was catalytically converted to $\mathrm{H}_{2}$ and $\mathrm{CO}_{2}$ by water gas shift reaction $\left(\mathrm{CO}+\mathrm{H}_{2} \mathrm{O} \rightarrow \mathrm{CO}_{2}+\mathrm{H}_{2}\right.$ ). From the ratio of $\mathrm{H}_{2}: \mathrm{CO}$ and $\mathrm{CO}_{2}: \mathrm{CO}$, we can predict whether water gas shift reaction occurs or not. Higher ratios of $\mathrm{H}_{2}$ : $\mathrm{CO}$ and $\mathrm{CO}_{2}$ : $\mathrm{CO}$ indicate that the catalyst enhances the water gas shift reaction. Fig. 4 shows the ratio of $\mathrm{H}_{2}: \mathrm{CO}$ and $\mathrm{CO}_{2}$ : $\mathrm{CO}$ for catalytic gasification. As can be seen from Fig. 4, the $\mathrm{CO}$ produced from the tar and char gasification was converted to $\mathrm{CO}_{2}$ and $\mathrm{H}_{2}$ by the water gas shift reaction in the presence of catalysts. This trend was similar to that observed for catalytic decomposition of biomass tar derived cedar wood with iron oxide catalysts [13]. In contrast, Tang et al. [27] reported a significant increase in CO production during the methane decomposition over ceria modified iron catalyst. They suggested that the interaction between carbon deposits and the lattice oxygen of $\mathrm{CeO}_{2}$ led to the formation of $\mathrm{CO}\left(\mathrm{C}+\mathrm{O}_{\mathrm{L}} \rightarrow \mathrm{CO}\right)$. But, in this study, the formed CO was consumed in water-gas shift reaction due to the presence of steam. It is clearly seen that $\mathrm{CeO}_{2}$, would not only disperse iron-containing species but also combine with the ironcontaining species to become involved in the catalytic reactions during steam gasification. It should be noted that the effect of $\mathrm{CeO}_{2}-\mathrm{Fe}_{2} \mathrm{O}_{3}$ weight ratio on the $\mathrm{H}_{2}: \mathrm{CO}$ and $\mathrm{CO}_{2}: \mathrm{CO}$ ratios is not simply monotonically increasing or decreasing.

In this study, the reforming of tar first took place on the catalyst, producing $\mathrm{CO}, \mathrm{H}_{2}, \mathrm{CO}_{2}, \mathrm{H}_{2} \mathrm{O}, \mathrm{CH}_{4}, \mathrm{C}_{2}$ and coke. The ion, basically from hematite to magnetite and from $\mathrm{Ce}^{4+}$ iron oxide and ceria was reduced during the reforming react to $\mathrm{Ce}^{3+}$. The reforming products $\mathrm{CO}, \mathrm{H}_{2}$ and $\mathrm{C}$ reduce the magnetite to wustite according to following reactions [28].

$$
\begin{aligned}
& \mathrm{Fe}_{3} \mathrm{O}_{4}+\mathrm{CO} \rightarrow \mathrm{FeO}+\mathrm{CO}_{2} \\
& \mathrm{Fe}_{3} \mathrm{O}_{4}+\mathrm{H}_{2} \rightarrow \mathrm{FeO}+\mathrm{H}_{2} \mathrm{O} \\
& \mathrm{Fe}_{3} \mathrm{O}_{4}+\mathrm{C} \rightarrow \mathrm{FeO}+\mathrm{CO}
\end{aligned}
$$

And then the reoxidizing of wustite to hematite with steam and CO produces $\mathrm{H}_{2}$ and $\mathrm{CO}_{2}$ (water-gas shift reaction). Because of its redox and oxygen storage capacity properties, it can be expected that similar reactions could take place over $\mathrm{CeO}_{2}$ [29]. In addition, $\mathrm{CeO}_{2}$ inhibit the 

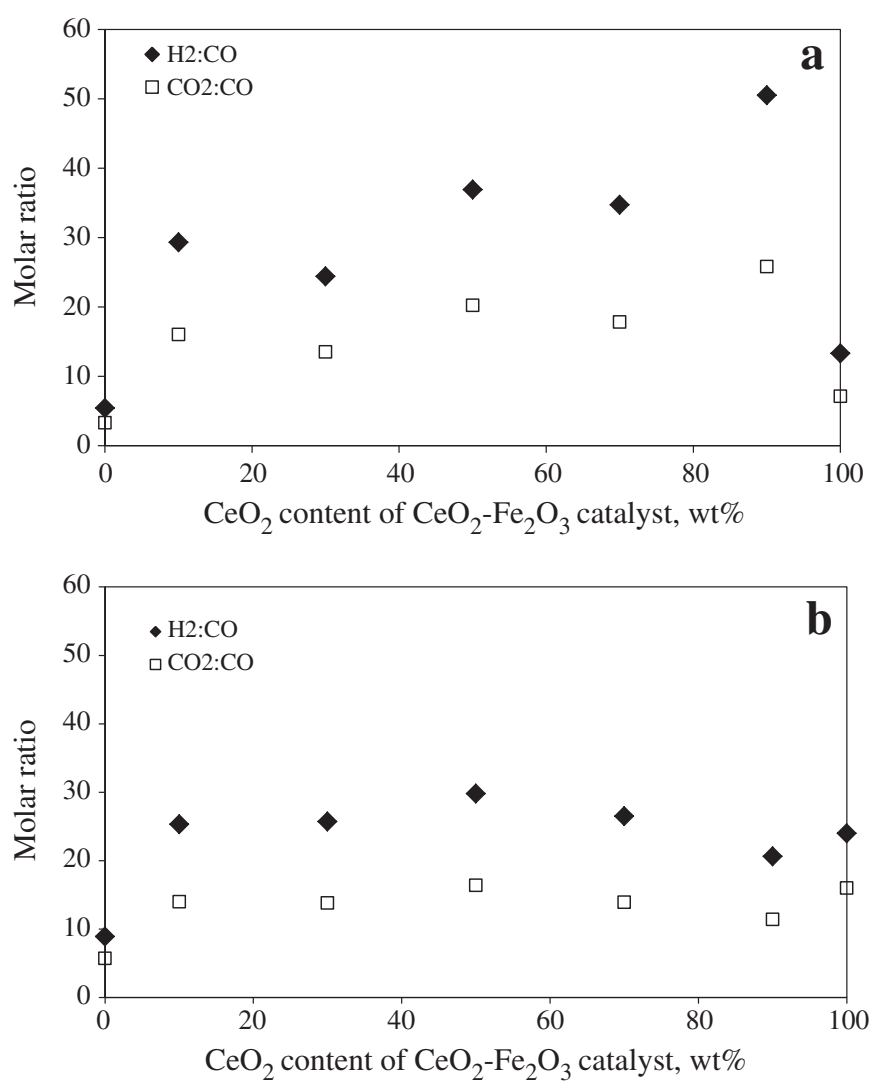

Fig. 4. Effect of $\mathrm{CeO}_{2}$ content of $\mathrm{CeO}_{2}-\mathrm{Fe}_{2} \mathrm{O}_{3}$ catalyst on $\mathrm{H}_{2}: \mathrm{CO}$ and $\mathrm{CO}_{2}: \mathrm{CO}$ ratios. The catalytic (bottom) bed temperature is (a) $600{ }^{\circ} \mathrm{C}$ and (b) $700{ }^{\circ} \mathrm{C}$.

formation of $\mathrm{C}$, which accumulate on iron oxide catalyst and decrease the catalytic activity.

Fig. 3 also shows the effect of the ratio of $\mathrm{CeO}_{2}$ on the activity of the $\mathrm{CeO}_{2}-\mathrm{Fe}_{2} \mathrm{O}_{3}$ catalysts. For the conditions of bottom bed temperature at $700{ }^{\circ} \mathrm{C}$, the $\mathrm{H}_{2}$ production was considerably enhanced by the addition of $10 \% \mathrm{CeO}_{2}$ but it did not change much with further increase in the ceria loading. However, in the case of catalytic gasification at $600{ }^{\circ} \mathrm{C}$, a high increase in $\mathrm{H}_{2}$ yield was obtained by the addition of $10 \% \mathrm{CeO}_{2}$ and then the $\mathrm{H}_{2}$ production slightly increased by ceria loading. The highest $\mathrm{H}_{2}$ yield was obtained by the addition of $90 \% \mathrm{CeO}_{2}$. It should be noted that at $700{ }^{\circ} \mathrm{C}$ in the bottom bed temperature, the yields of gas were not very different from that at $600{ }^{\circ} \mathrm{C}$.

Although the addition of $\mathrm{CeO}_{2}$ to $\mathrm{Fe}_{2} \mathrm{O}_{3}$ enhanced the hydrogen production, the pure $\mathrm{CeO}_{2}$ was less active in hydrogen production than $\mathrm{CeO}_{2}-\mathrm{Fe}_{2} \mathrm{O}_{3}$ catalysts. He and co-workers [25], have investigated the methane conversion and reported that the composite oxygen carriers $(\mathrm{Ce}-\mathrm{Fe}-\mathrm{O})$ have better reactivity than the pure $\mathrm{CeO}_{2}$.

\subsubsection{Effect of catalyst on tar decomposition}

As we mentioned above, it was not possible to collect tar product perfectly in our micro-system, so the results relating to tar decomposition were given on the basis of carbon amounts in gas products. Tar conversion was determined by the comparison of carbon amounts between catalytic runs and thermal runs.

The tar conversion is defined as;

$\%$ tar conversion $=\frac{A}{B} \times 100$

where; $A$ is the amount of carbon in all carbonaceous gasses collected in a catalytic run (during the top bed or biomass bed temperature ramped from $200{ }^{\circ} \mathrm{C}$ to $500{ }^{\circ} \mathrm{C}$ ) when the catalytic bed was kept constant at specific temperature $\left(600{ }^{\circ} \mathrm{C}\right.$ or $700{ }^{\circ} \mathrm{C}$ or $\left.850{ }^{\circ} \mathrm{C}\right)$; and $B$ is the maximum amount of carbon in carbonaceous gasses emitted in the thermal run (during the top bed or biomass bed temperature ramped from $200{ }^{\circ} \mathrm{C}$ to $500{ }^{\circ} \mathrm{C}$ ) when bottom bed temperature was kept at $850{ }^{\circ} \mathrm{C}$ without any catalyst.

In this study, maximum amount of carbonaceous gasses emitted from tar decomposition in thermal run was found as $52 \%$ of the total carbon in biomass when the bottom bed temperature was kept at $850{ }^{\circ} \mathrm{C}$ without any catalyst. Therefore, in a catalytic run at a particular condition if $52 \%$ of total carbon in biomass evolved from tar decomposition (during the top bed or biomass bed temperature ramped from $200{ }^{\circ} \mathrm{C}$ to $500{ }^{\circ} \mathrm{C}$ ), then tar decomposition rate on that particular catalyst under that particular condition would be calculated to be $100 \%$. The tar conversion results of the catalytic experiments are shown in Fig. 3.

Compared to the thermal runs at low temperatures (600 and $700{ }^{\circ} \mathrm{C}$ ), catalytic gasification significantly increased the tar degradation. At $700{ }^{\circ} \mathrm{C}$ of catalytic bed temperature, the tar conversions in excess of $90 \%$ were obtained for all catalysts with the exception of $100 \% \mathrm{Fe}_{2} \mathrm{O}_{3}$. Although iron-based catalysts are known for their high tar cracking activity, $\mathrm{Fe}_{2} \mathrm{O}_{3}$ exhibited lower tar conversion capacity compared to $\mathrm{CeO}_{2}$ at both 600 and $700{ }^{\circ} \mathrm{C}$. This is easily understood because of the fact that degradation of tar and iron oxide reductions which are endothermic reactions is more effective at high temperature $\left(\geq 850{ }^{\circ} \mathrm{C}\right)$ [28]. Bleeker et al. have studied the gasification of bio-oil in the steam-iron process and reported that the overall conversion of pyrolysis oil to the gas phase increased from $51 \%$ at $750{ }^{\circ} \mathrm{C}$ to $70 \%$ at $900{ }^{\circ} \mathrm{C}[30]$. It is interesting to note that although $\mathrm{Fe}_{2} \mathrm{O}_{3}$ alone showed no tar cracking activity at $600{ }^{\circ} \mathrm{C}$, it led to an increase in hydrogen production at $600{ }^{\circ} \mathrm{C}$. Matsuoka et al. studied the steam reforming of oak sawdust at two different temperatures $\left(500\right.$ and $\left.700{ }^{\circ} \mathrm{C}\right)$ in the twostage fluidized bed reactor on iron oxide-impregnated $\gamma-\mathrm{Al}_{2} \mathrm{O}_{3}$. and they also observed $\mathrm{H}_{2}$ formation at low temperature (at $500{ }^{\circ} \mathrm{C}$ ) [14]. And they suggested that the catalytic activity of the iron oxide was evident in the presence of steam at higher temperatures and dominant pathway of $\mathrm{H}_{2}$ formation at low temperature was due to the cracking of the coke on the iron oxide particles.

On the other hand, $\mathrm{CeO}_{2}$ was more effective in reforming of tar due to the redox property and the high ability of lattice oxygen compared to iron oxide. Because of this, the addition of $\mathrm{CeO}_{2}$ to $\mathrm{Fe}_{2} \mathrm{O}_{3}$ increased tar conversion activity of the catalyst at low temperatures. In addition to the redox property of $\mathrm{CeO}_{2}$, the addition of $\mathrm{CeO}_{2}$ to $\mathrm{Fe}_{2} \mathrm{O}_{3}$ may improve the basic nature of iron oxide [25]. Ashok and Kawi [29] have also reported that the addition of $\mathrm{CeO}_{2}$ to $\mathrm{Ca}-\mathrm{Al}$ support increased the basic strength of the catalyst which enhances the reaction between steam and carbon and also suppresses the coke formation via neutralization of the support acidity. It is worth noticing that the pure $\mathrm{CeO}_{2}$ showed lower tar cracking activity than $50 \% \mathrm{CeO}_{2}-50 \% \mathrm{Fe}_{2} \mathrm{O}_{3}$ and $30 \%$ $\mathrm{CeO}_{2}-70 \% \mathrm{Fe}_{2} \mathrm{O}_{3}$, possibly due to the formation of catalytically active centers at the interface of iron oxide and ceria.

Although, the temperature of catalyst bed had no considerable effect on hydrogen production, it affected the tar decomposition. As can be seen from Fig. 3, tar conversions at $600{ }^{\circ} \mathrm{C}$ are lower than at $700{ }^{\circ} \mathrm{C}$ for all tested catalysts. It can be concluded that the catalyst bed temperature had a significant effect on the tar degradation rather than composition of the catalyst. It is difficult to draw a clear correlation between tar conversion and catalyst surface area. The extent of the decrease in surface area of the $\mathrm{CeO}_{2}-\mathrm{Fe}_{2} \mathrm{O}_{3}$ catalysts is dependent on the $\mathrm{Fe}_{2} \mathrm{O}_{3}$ content of the catalysts: the surface area decreased with the increase of iron oxide content of the catalysts (Table 1 ). This trend was similar to that observed for iron-aluminum catalyst which was used for steam reforming of naphthalene [15]. As a conclusion, a tar conversion of $100 \%$ was achieved by $50 \% \mathrm{CeO}_{2}-\% 50 \mathrm{Fe}_{2} \mathrm{O}_{3}$ at the catalyst bed temperature of $700{ }^{\circ} \mathrm{C}$. This was an improvement of about $86 \%$ over the noncatalytic results at the same temperature. The better performance of $50 \% \mathrm{CeO}_{2}-50 \% \mathrm{Fe}_{2} \mathrm{O}_{3}$ may be correlated with the amount of active centers. Thus, the interface between iron oxide and ceria at this 
composition may generate maximum number of catalytically active centers. By considering the interface of iron oxide and ceria, it may also promote the water gas shift reaction (as can be seen that either $100 \% \mathrm{Fe}_{2} \mathrm{O}_{3}$ or $100 \% \mathrm{CeO}_{2}$ has lower activity for $\mathrm{CO}$ shift reaction).

\subsection{Catalyst characterization}

To determine the form of the iron oxide and ceria during the steam gasification, we performed $\mathrm{X}$-ray diffraction analysis of the some of the catalysts $\left(100 \% \mathrm{Fe}_{2} \mathrm{O}_{3}, 100 \% \mathrm{CeO}_{2}\right.$ and $50 \% \mathrm{CeO}_{2}-50 \% \mathrm{Fe}_{2} \mathrm{O}_{3}$ ) before and after steam gasification (Fig. 5). As expected, XRD patterns of $100 \%$ $\mathrm{CeO}_{2}$ correspond to ceria with cubic fluorite type structure and the strong intensity of the diffraction peaks may indicate that the crystallite size of catalyst is large [31]. For the $100 \% \mathrm{Fe}_{2} \mathrm{O}_{3}$ catalyst, only hematite $\left(\alpha-\mathrm{Fe}_{2} \mathrm{O}_{3}\right)$ peaks were observed. On the other hand, in the fresh $50 \%$ $\mathrm{CeO}_{2}-50 \% \mathrm{Fe}_{2} \mathrm{O}_{3}$ catalyst, diffraction peaks due to the presence of $\alpha-\mathrm{Fe}_{2} \mathrm{O}_{3}$ and $\mathrm{CeO}_{2}$ are evidenced in the XRD pattern. It should be
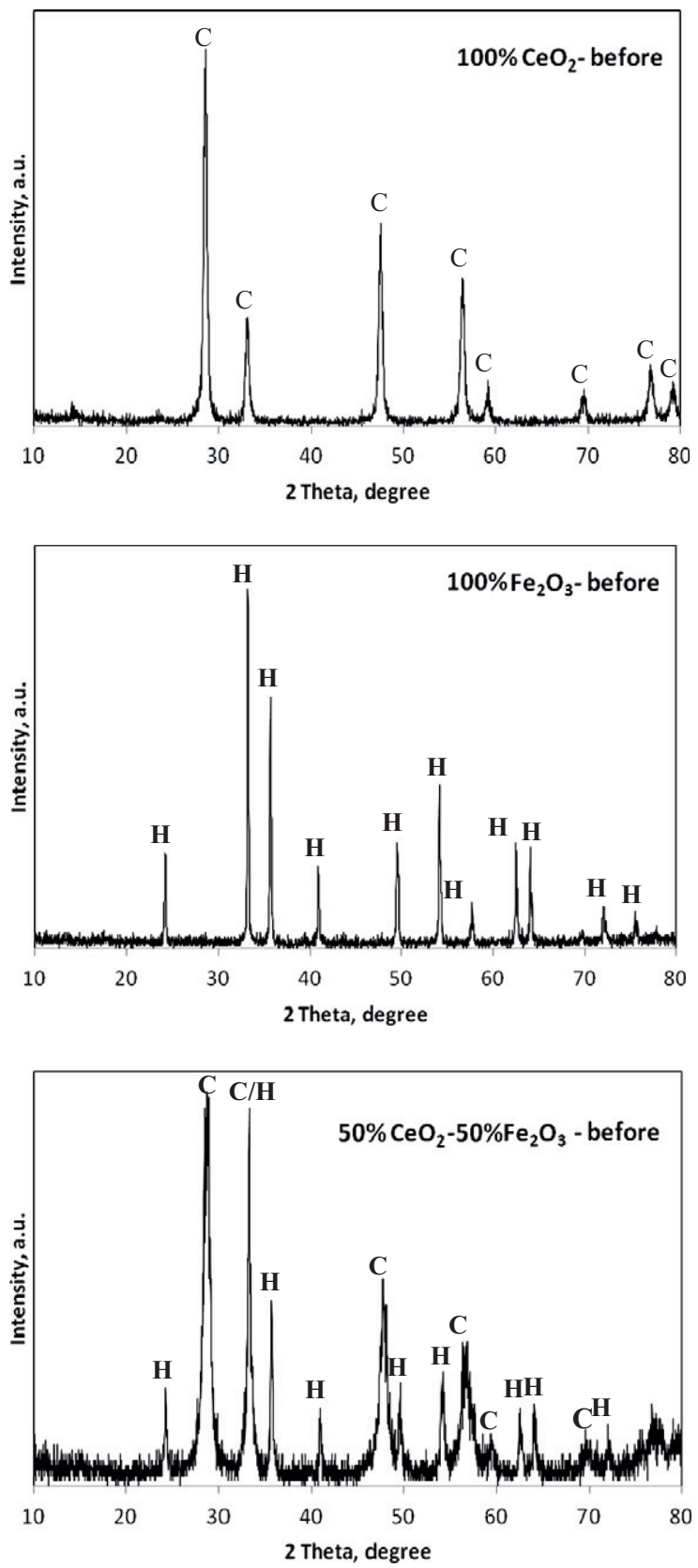

noted that the diffraction peaks of $50 \% \mathrm{CeO}_{2}-50 \% \mathrm{Fe}_{2} \mathrm{O}_{3}$ were broader than those of $100 \% \mathrm{Fe}_{2} \mathrm{O}_{3}$ and $100 \% \mathrm{CeO}_{2}$, which shows the presence of smaller crystallites [27]. Tang et al. have reported that the Fe-Ce interaction occurred through the formation of hematite-like solutions, the $\mathrm{Ce}^{4+}$ cations substituted $\mathrm{Fe}^{3+}$ cations in the lattice, when the contents of iron and ceria were approximately equal [27]. It may be suggested that ceria support would not only disperse the iron-containing species but also interact with the iron-containing species to become involved in the catalytic reactions during tar gasification. After gasification, the hematite peaks disappeared and magnetite $\left(\mathrm{Fe}_{3} \mathrm{O}_{4}\right)$ peaks were observed. Similarly, for the post-used $50 \% \mathrm{CeO}_{2}-50 \% \mathrm{Fe}_{2} \mathrm{O}_{3}$ catalyst, the reflection of $\mathrm{Fe}_{2} \mathrm{O}_{3}$ disappeared and peaks for $\mathrm{Fe}_{3} \mathrm{O}_{4}$ were observed, whereas the XRD pattern of the $\mathrm{CeO}_{2}$ remained almost the same. These results demonstrated that all $\mathrm{Fe}_{2} \mathrm{O}_{3}$ were reduced to $\mathrm{Fe}_{3} \mathrm{O}_{4}$ during the steam gasification, as previously reported [13]. It should be noted that no peaks corresponding to wustite and the metallic Fe phase were identified.
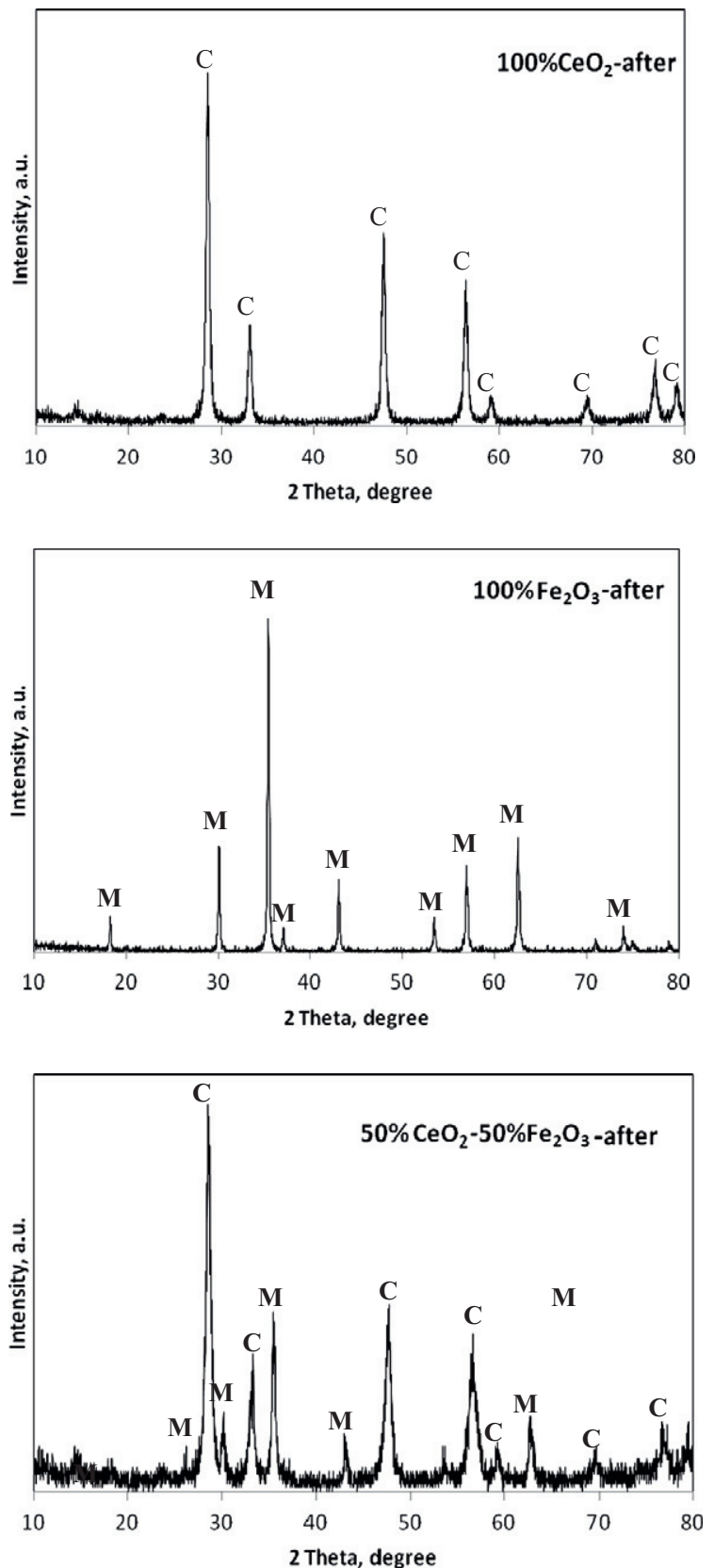

Fig. 5. X-ray diffraction patterns of the catalysts before and after the steam gasification. $\mathrm{C}$ : $\mathrm{CeO}_{2}$, $\mathrm{M}$ : Magnetite, $\mathrm{H}$ : Hematite. 


\section{Conclusion}

In this study, steam gasification of safflower seed cake was carried out using a flow-type reactor in a two step process at two different catalytic bed temperatures in the presence of $\mathrm{CeO}_{2}-\mathrm{Fe}_{2} \mathrm{O}_{3}$ catalysts. Catalytic performance of $\mathrm{CeO}_{2}-\mathrm{Fe}_{2} \mathrm{O}_{3}$ catalysts with the optimum composition was much higher than the corresponding individual metal oxide catalysts in the steam gasification of biomass. Temperature had significant effects on the tar conversion: tar conversion increased when the bed temperature was increased from $600{ }^{\circ} \mathrm{C}$ to $700{ }^{\circ} \mathrm{C}$, whereas the yield of hydrogen is dependent on the catalyst type. The tar decomposition was completed on $50 \% \mathrm{CeO}_{2}-50 \% \mathrm{Fe}_{2} \mathrm{O}_{3}$ at $700{ }^{\circ} \mathrm{C}$. The highest $\mathrm{H}_{2}$ yield was obtained with $90 \% \mathrm{CeO}_{2}-10 \% \mathrm{Fe}_{2} \mathrm{O}_{3}$ $\left(1465 \mathrm{~cm}^{3} / \mathrm{g}\right)$ and $50 \% \mathrm{CeO}_{2}-50 \% \mathrm{Fe}_{2} \mathrm{O}_{3}\left(1492 \mathrm{~cm}^{3} / \mathrm{g}\right)$ at 600 and $700{ }^{\circ} \mathrm{C}$, respectively. There was no significant influence of catalyst on $\mathrm{CH}_{4}$ production. The enhancement of catalytic activity of $\mathrm{CeO}_{2}-\mathrm{Fe}_{2} \mathrm{O}_{3}$ catalysts could be attributed to the red-ox properties of the catalysts and the addition of $\mathrm{CeO}_{2}$ to $\mathrm{Fe}_{2} \mathrm{O}_{3}$ improved the catalytic stability of iron based catalysts for tar degradation and hydrogen production via water-gas shift reaction in steam gasification. From the considerations that iron is cheap in price compared to noble metals and nickel and it is non-toxic, we suggest that the combination of iron oxide with ceria could produce effective catalysts for secondary downstream treatment of biomass tars for both economic and environmental reasons.

\section{Acknowledgments}

We would like to acknowledge FP7 Marie-Curie IRSES project no: 247550 for the financial support. We also thank to Prof. Dr. Yoshiei Kato for his collaboration and invitation to Environmental Analytical Chemistry Laboratory, Okayama University.

\section{References}

[1] F. Mermoud, S. Salvador, L. Van de Steene, F. Golfier, Influence of the pyrolysis heating rate on the steam gasification rate of large wood char particles, Fuel 85 (2006) 1473-1482

[2] K. Matsumoto, K. Takeno, T. Ichinose, T. Ogi, M. Nakanishi, Gasification reaction kinetics on biomass char obtained as a by-product of gasification in an entrainedflow gasifier with steam and oxygen at 900-1000 ${ }^{\circ} \mathrm{C}$, Fuel 88 (2009) 519-527.

[3] J.Han, H. Kim, The reduction and control technology of tar during biomass gasification/ pyrolysis: an overview, Renewable and Sustainable Energy Reviews 12 (2008) 397-416.

[4] S. Rapagná, N. Jand, A. Kiennemann, P.U. Foscolo, Steam-gasification of biomass in a fluidised-bed of olivine particles, Biomass and Bioenergy 19 (2000) 187-197.

[5] J. Corella, J.M. Toledo, R. Padilla, Olivine or dolomite as in bed additive in biomass gasification with air in a fluidized bed: which is better? Energy \& Fuels 18 (2004) 713-720.

[6] C.E. Efika, C. Wu, P.T. Williams, Syngas production from pyrolysis-catalytic steam reforming of waste biomass in a continuous screw kiln reactor, Journal of Analytical and Applied Pyrolysis 95 (2012) 87-94.

[7] Q. Xie, S. Kong, Y. Liu, H. Zeng, Syngas production by two-stage method of biomass catalytic pyrolysis and gasification, Bioresource Technology 110 (2012) 603-609.

[8] J.M. Encinar, J.F. González, G. Martínez, J.M. González, Two stages catalytic pyrolysis of olive oil waste, Fuel Processing Technology 89 (2008) 1448-1455.
[9] Y.R. Xie, L.H. Shen, J. Xiao, D.X. Xie, J. Zhu, Influences of additives on steam gasification of biomass. 1. Pyrolysis procedure, Energy \& Fuels 23 (2009) 5199-5205.

[10] L. Devi, M. Craje, P. Thüne, K.J. Ptasinski, F.J.G. Janssen, Olivine as tar removal catalyst for biomass gasifiers: catalyst characterization, Applied Catalysis A: General 294 (2005) 68-79.

[11] C. Rioche, S. Kulkarni, F.C. Meunier, J.P. Breen, R. Burch, Steam reforming of model compounds and fast pyrolysis bio-oil on supported noble metal catalysts, Applied Catalysis B: Environmental 61 (2005) 130-139.

[12] E. Gusta, A.K. Dalai, M.A. Uddin, E. Sasaoka, Catalytic decomposition of biomass tars with dolomites, Energy \& Fuels 23 (2009) 2264-2272.

[13] M.A. Uddin, H. Tsuda, S. Wu, E. Sasaoka, Catalytic decomposition of biomass tars with iron oxide catalysts, Fuel 87 (2008) 451-459.

[14] T. Matsuoka, K. Shimbori, H. Kuramoto, Y. Suzuki, Steam reforming of woody biomass in a fluidized bed of iron oxide-impregnated porous alumina, Energy \& Fuels 20 (2006) 2727-2731.

[15] H. Noichi, A. Uddin, E. Sasaoka, Steam reforming of naphthalene as model biomass tar over iron-aluminum and iron-zirconium oxide catalyst catalysts, Fuel Processing Technology 91 (2010) 1609-1616.

[16] K. Matsuoka, T. Shinbori, K. Kuramoto, T. Nanba, A. Morita, H. Hatano, Y. Suzuki, Mechanism of woody biomass pyrolysis and gasification in a fluidized bed of porous alumina particles, Energy \& Fuels 20 (2006) 1315-1320.

[17] T. Kimura, T. Miyazawa, J. Nishikawa, S. Kado, K. Okumura, T. Miyao, S. Naito, K. Kunimori, K. Tomishige, Development of Ni catalysts for tar removal by steam gasification of biomass, Applied Catalysis B: Environmental 68 (2006) 160-170.

[18] M.M. Yung, W.S. Jablonski, K.A. Magrini-Bair, Review of catalytic conditioning of biomass-derived syngas, Energy \& Fuels 23 (2009) 1874-1887.

[19] Y. Li, B. Zhang, X. Tang, Y. Xu, W. Shen, Hydrogen production from methane decomposition over $\mathrm{Ni} / \mathrm{CeO}_{2}$ catalysts, Catalysis Communications 7 (2006) 380-386

[20] R. Zhang, Y. Wang, R. Brown, Steam reforming of tar compounds over Ni/olivine catalysts doped with $\mathrm{CeO}_{2}$, Energy Conversion and Management 48 (2007) 68-77.

[21] M. Asadullah, S. Ito, K. Kunimori, M. Yamada, K. Tomishige, Energy efficient production of hydrogen and syngas from biomass: development of low-temperature catalytic process for cellulose gasification, Environmental Science \& Technology 36 (2002) 4476-4481.

[22] T. Miyazawa, T. Kimura, J. Nishikawa, S. Kado, K. Kunimori, K. Tomishige, Catalytic performance of supported Ni catalysts in partial oxidation and steam reforming of tar derived from the pyrolysis of wood biomass, Catalysis Today 115 (2006) 254-262.

[23] C. Wu, P.T. Williams, Ni/CeO2/ZSM-5 catalysts for the production of hydrogen from the pyrolysis-gasification of polypropylene, International Journal of Hydrogen Energy 34 (2009) 6242-6252.

[24] J. Nishikawa, T. Miyazawa, K. Nakamura, M. Asadullah, K. Kunimori, K. Tomishige, Promoting effect of Pt addition to $\mathrm{Ni} / \mathrm{CeO}_{2} / \mathrm{Al}_{2} \mathrm{O}_{3}$ catalyst for steam gasification of biomass, Catalysis Communications 9 (2) (2008) 195-201.

[25] F. He, Y. Wei, H. Li, H. Wang, Synthesis gas generation by chemical-looping reforming using Ce-based oxygen carriers modified with $\mathrm{Fe}, \mathrm{Cu}$, and $\mathrm{Mn}$ oxides, Energy \& Fuels 23 (2009) 2095-2102.

[26] S.T. Chaudhari, S.K. Bej, N.N. Bakhshi, A.K. Dalai, Steam gasification of biomassderived char for the production of carbon monoxide-rich synthesis gas, Energy \& Fuels 15 (2001) 736-742.

[27] L. Tang, D. Yamaguchi, N. Burke, D. Trimm, K. Chiang, Methane decomposition over ceria modified iron catalysts, Catalysis Communications 11 (2010) 1215-1219.

[28] M.F. Bleeker, H.J. Veringa, S.R.A. Kersten, Pure hydrogen production from pyrolysis oil using the steam-iron process: effects of temperature and iron oxide conversion in the reduction, Industrial and Engineering Chemistry Research 49 (2010) 53-64.

[29] J. Ashok, S. Kawi, Steam reforming of toluene as a biomass tar model compound over $\mathrm{CeO}_{2}$ promoted $\mathrm{Ni} / \mathrm{CaO}-\mathrm{Al}_{2} \mathrm{O}_{3}$ catalytic systems, International Journal of Hydrogen Energy 38 (2013) 13938-13949.

[30] M.F. Bleeker, S.R.A. Kersten, H.J. Veringa, Pure hydrogen from pyrolysis oil using the steam-iron process, Catalysis Today 127 (2007) 278-290.

[31] C.G. Maciela, T.F. Silva, L.P.R. Profeti, E.M. Assaf, J.M. Assaf, Study of $\mathrm{CuO} / \mathrm{CeO}_{2}$ catalyst with for preferential $\mathrm{CO}$ oxidation reaction in hydrogen-rich feed [PROX-CO], Applied Catalysis A: General 431 (2012) 25-32. 